\title{
Ocular Problems Following Lightning Strike Injury: A Case Report
}

\author{
Yıldırım Çarpması Sonrasında Gelișen Göz Problemleri: Olgu Sunumu
}

\author{
Erel İçel', Adem Türk², Turgay Uçak', Yücel Karakurt', Nurdan Gamze Tașlı', Sümeyye Burcu Ağcayazı' \\ ${ }^{I}$ Department OfOphthalmology, Erzincan Binali Yildrrm University Mengücek Gazi Education and Research Hospital, Erzincan; \\ ${ }^{2}$ Department OfOphthalmology, Karadeniz Technical University, Trabzon, Turkey
}

\begin{abstract}
We were consulted about suddenly occurring ocular symptoms in a 28-year-old woman with burns on her left foot on the same day after a lightning strike. The best corrected visual acuity (BCVA) values in the right and left eyes were LogMAR 0.09 and 0.69, respectively. The intraocular pressure (IOP) was $7 \mathrm{mmHg}$ on the right and $4 \mathrm{mmHg}$ on the left. Conjunctival hyperemia and corneal punctate epitheliopathy were present in the left eye at the biomicroscopic examination. Dilated fundus examination was normal in the right eye. In the left eye, the optic disc was normal but the macula was slightly pigmented. At the follow-up examinations performed 3 days later, visual acuity was normal in the right eye and it was 0.04 (LogMAR) in the left eye. In the right eye macula was normal and in the left eye maculopathy was present at fundus examination. An iridocyclitis attack developed in the left eye in the following 3 months and cataract was observed in the left eye in the 5th-month follow-up. At the 12th follow-up visit, visual acuity was unimpaired bilaterally and IOPs of both eyes were normal. No progression was determined in the cataract in the left eye. Bilateral OCT images were normal.
\end{abstract}

Key words: cataract; eye injuries; lightning injuries; ocular hypotension

\section{ÖZET}

Yıldırım çarpması sonrası sol ayak yanığı gelișen 28 yașında kadın hasta aynı gün ani göz semptomları gelișmesi üzerine tarafımıza konsülte edildi. Olgunun tashihli görme seviyeleri sağda ve solda LogMAR ile 0.00 ve 0.69 idi. Göz içi basıncı (GiB) değerleri sağda 7, solda $4 \mathrm{mmHg}$ idi. Biyomikroskopik muayenesinde sağ göz normal görünümde, sol gözde konjonktival hiperemi, korneal punktat epitelyopati mevcuttu. Dilate fundus muayenesinde sağ göz normaldi. Sol gözde optik disk normal ancak makula bir miktar pigmente görünümdeydi. Hastanın üç gün sonraki kontrolünde görme seviyeleri sağda LogMAR ile 0.00; solda 0.04, fundus incelemesinde ise sağ göz makula normaldi ve sol gözde makulopati mevcuttu. Hastanın sol gözünde 3 ay sonra iridosiklit atağı geliști ve 5 ay sonraki kontrolde sol gözde katarakt gelișimi saptandığı görüldü. 12. ay kontrolünde görme seviyeleri bilateral 0.00, göziçi basınçları normaldi. Sol göz katarakt seviyesinde ilerleme saptanmadı. Bilateral OKT görüntüleri normaldi.

Anahtar kelimeler: göz hipotansiyonu; göz yaralanmaları; katarakt; șimșek hasarları

\section{Background}

Lightning-related electric shocks may result in severe mortality (20-30\%) and morbidity (75\%), and can lead to permanent sequelae ${ }^{1-3}$. Asystolic cardiac arrest and ventricular fibrillation are among the most common causes of mortality ${ }^{4}$. Ophthalmological examination is particularly important for screening any potential injury to the eye, since the risk of developing ocular findings is as high as 50\% after a lightning strike. Particular care must be taken in screening and monitoring these patients for several potential eye injuries including chemosis, necrotic eyelid lesions, thermal keratopathy, uveitis, hyphema, anterior and posterior subcapsular cataract, lens dislocation, vitreous hemorrhage, retinal detachment, retinal hemorrhage, cystoid macular edema, chorioretinal rupture, macular hole, and occlusion of the central retinal artery and vein ${ }^{5-9}$. Potential neurological complications involving the eye include thermal papillitis, optic neuropathy, loss of pupillary light reflex, anisocoria, Horner syndrome, and multiple facial nerve palsy ${ }^{9,10}$. The most common permanent sequela in the eye after 
a lightning strike is cataract formation since the lens is highly sensitive to the heat generated by electric current $^{8}$. Inflammatory changes frequently occur in the iris and ciliary body, and moderately severe and temporary iritis may be observed in 1-8 weeks after the trauma ${ }^{11}$. The macular region is also highly sensitive to thermal damage because of the resistance to the electrical current by the melanin-rich retinal pigment epithelium, resulting in a variety of macular injury findings ${ }^{12}$.

This report discusses the anterior and posterior segment complications developing in the eye after a lightning strike injury. The written informed consent was obtained from the patient.

\section{Case Report}

We were consulted about a sudden occurrence of ocular symptoms in a patient with burn lesions on her left foot on the same day after a lightning strike. The patient was monitored for potential cardiac complications. No systemic medical treatments were administered. At the ophthalmological examination, direct and indirect light reflexes, color vision as assessed by the Ishihara test, and the eye movements were normal in both eyes. BCVA values were 0.09 (LogMAR) on the right and 0.69 on the left. Intraocular pressure (IOP), measured using a non-contact tonometer, was $7 \mathrm{~mm} \mathrm{Hg}$ on the right and $4 \mathrm{~mm} \mathrm{Hg}$ on the left. The right eye was normal in appearance at the biomicroscopic examination, while conjunctival hyperemia and corneal punctate epitheliopathy were present in the left eye. The corneas were transparent (central pachymetry $\mathrm{OD}=538, \mathrm{OS}=597 \mu \mathrm{m}$ ) bilaterally. The anterior chamber depth $(\mathrm{OD}=3.61, \mathrm{OS}=3.54 \mathrm{~mm})$ was normal, and no anterior chamber reaction or crystalline lens problem was determined. Angle appearance at gonioscopy was normal. Fundus examination revealed a cup-disc ratio $(\mathrm{C} / \mathrm{D})$ of 0.4 with normal macula in the right eye and a $C / D$ of 0.5 with some degree of macular pigmentation in the left eye. Medical treatment started, consisting of topical antibiotics and artificial tear. Visual evoked potentials and a computed tomography imaging of the brain performed on the same day revealed normal findings.

At the follow-up examination on the following day, the patient's symptoms had improved. Her visual acuity values were LogMAR 0.09 in the right and the left eye, and her IOP values increased to $10 \mathrm{mmHg}$, bilaterally. The left corneal epithelial defect improved as observed in the biomicroscopic examination. The macular optic coherence tomography revealed normal findings in the right eye (Figure 1), and the findings on the left eye were compatible with the impairment in the IS/ OS band in the left eye (Figure 2). Macular thicknesses were $245 \mu \mathrm{m}$ on the right and $256 \mu \mathrm{m}$ on the left, while peripapillary retinal nerve fiber layer thicknesses were $98 \mu \mathrm{m}$ and $119 \mu \mathrm{m}$, respectively.

At the follow-up examination on day 3, visual acuity values were completely normal on the right and 0.04 (LogMAR) on the left, while IOP values were $9 \mathrm{mmHg}$ and $7 \mathrm{mmHg}$, respectively. Both eyes appeared natural at the biomicroscopic examination (central pachymetry $\mathrm{OD}=519$, $\mathrm{OS}=537 \mu \mathrm{m})$. At fundus examination macula was normal in the right eye and maculopathy was identified in the left eye (Figure 3). The macular OCT showed normal findings in the right eye and revealed a subfoveal pseudocyst in the left eye (Figure 4). The patient's visual acuity was good, and the patient was recommended to attend the scheduled follow-up visits.

The patient presented with a complaint of redness in the left eye after three months. In the ophthalmic examination, the visual acuity was unimpaired in both eyes and was 0.69 both in the right and left eyes. IOP values were $11 \mathrm{mmHg}$ bilaterally. At the biomicroscopic examination; the right eye was normal, the cornea was transparent, Tyndall value was +2 , and the lens was normal. The findings observed at the fundus examination were stable. Topical steroid drops started to treat the left eye with dilatation. She attended the next follow-up visit in month 5 . We were informed that she had complied with the treatment only for 2 weeks and then stopped. The visual acuity was unimpaired in both eyes. IOP values were $12 \mathrm{mmHg}$ in the right eye and $11 \mathrm{mmHg}$ in the left. The biomicroscopic examination findings of the right eye were normal while an occasional opacity was observed in the left lens (Figure 5). On detailed fundus examination macula were normal in both eyes. At macular OCT, the right eye was normal, and the subfoveal pseudocyst in the left eye, previously detected on day 5 after the injury, had disappeared (Figure 6).

The patient's bilateral visual acuity was unimpaired at the follow-up visit in month 12, and IOPs were normal. The biomicroscopic examination findings were normal and no progression was detected in the degree of the left eye cataract. Bilateral fundus and OCT images were normal. 


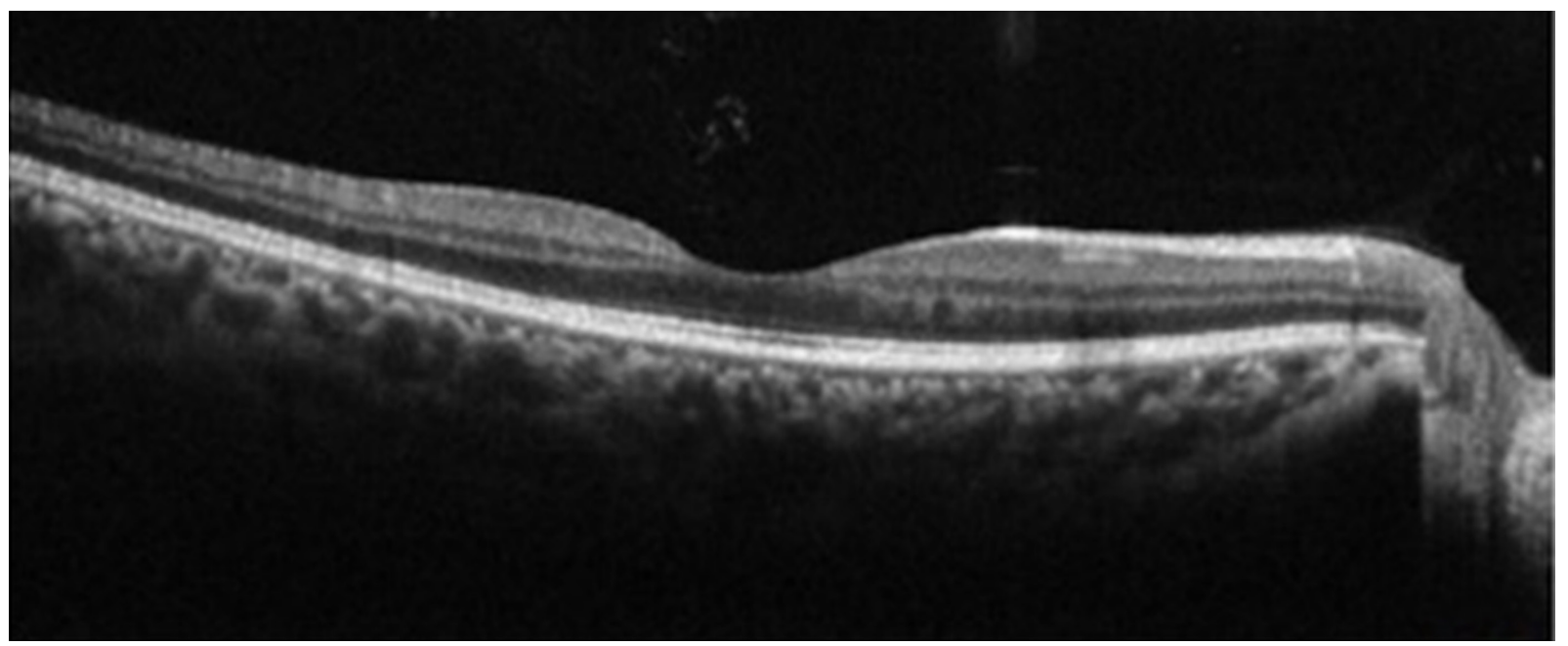

Figure 1. Macular OCT image of the right eye on day 2.

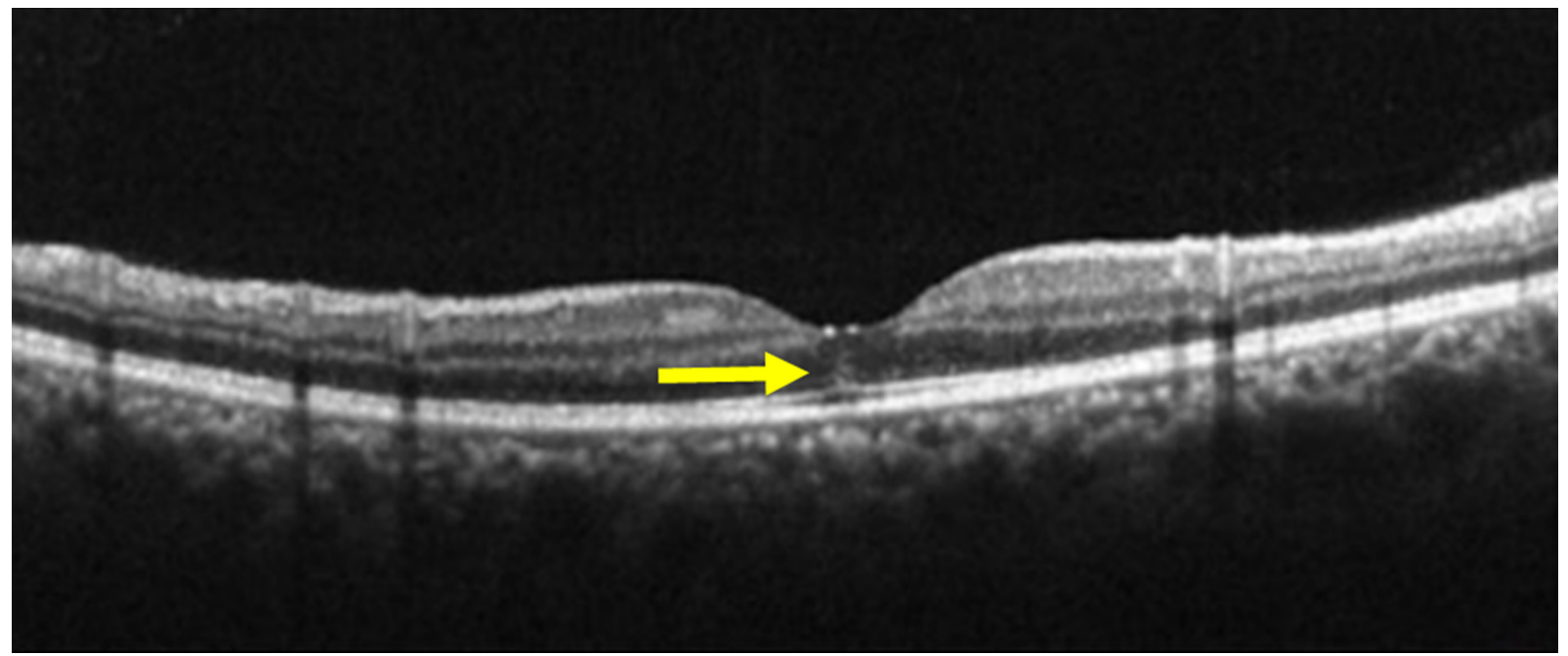

Figure 2. Changes in the ISOS band were present on day 2 at OCT (Left Eye).

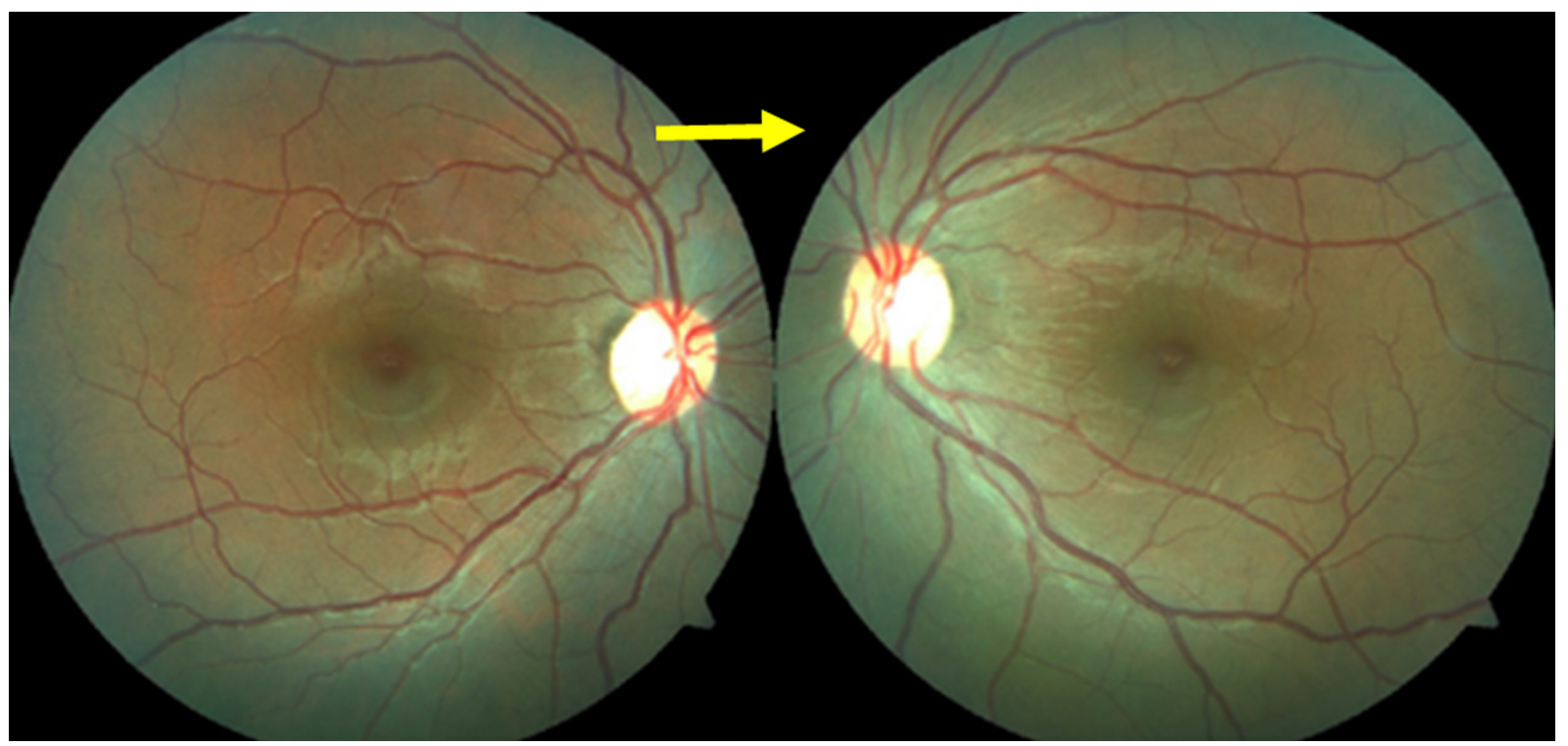

Figure 3. Bilateral fundus photographs on day 5. 


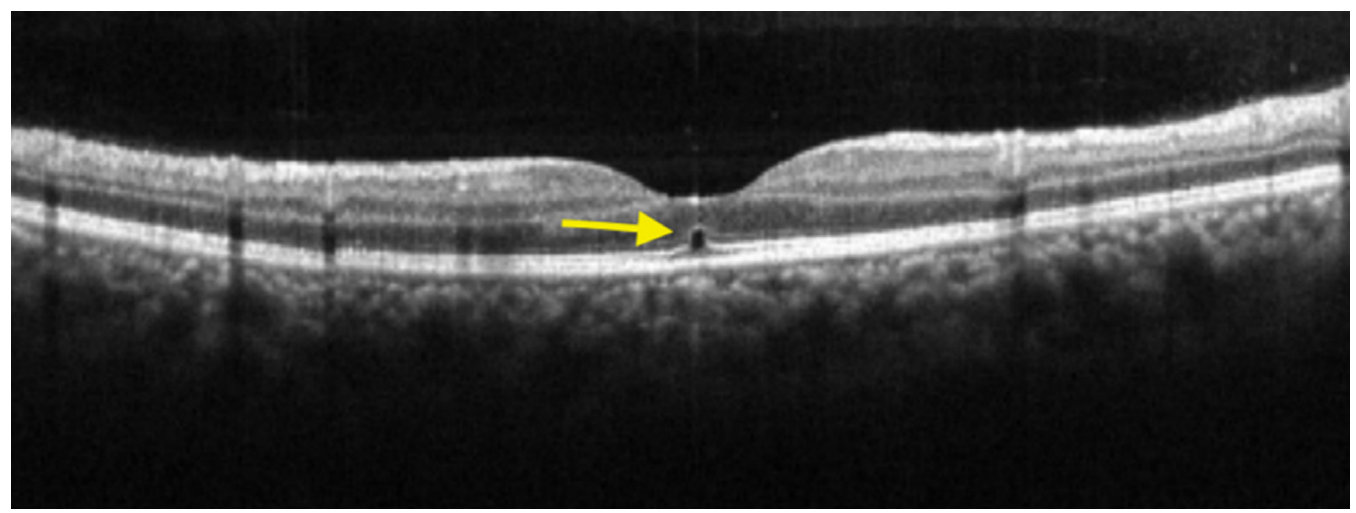

Figure 4. Subfoveal pseudocyst at macular OCT of the left eye on day 5.

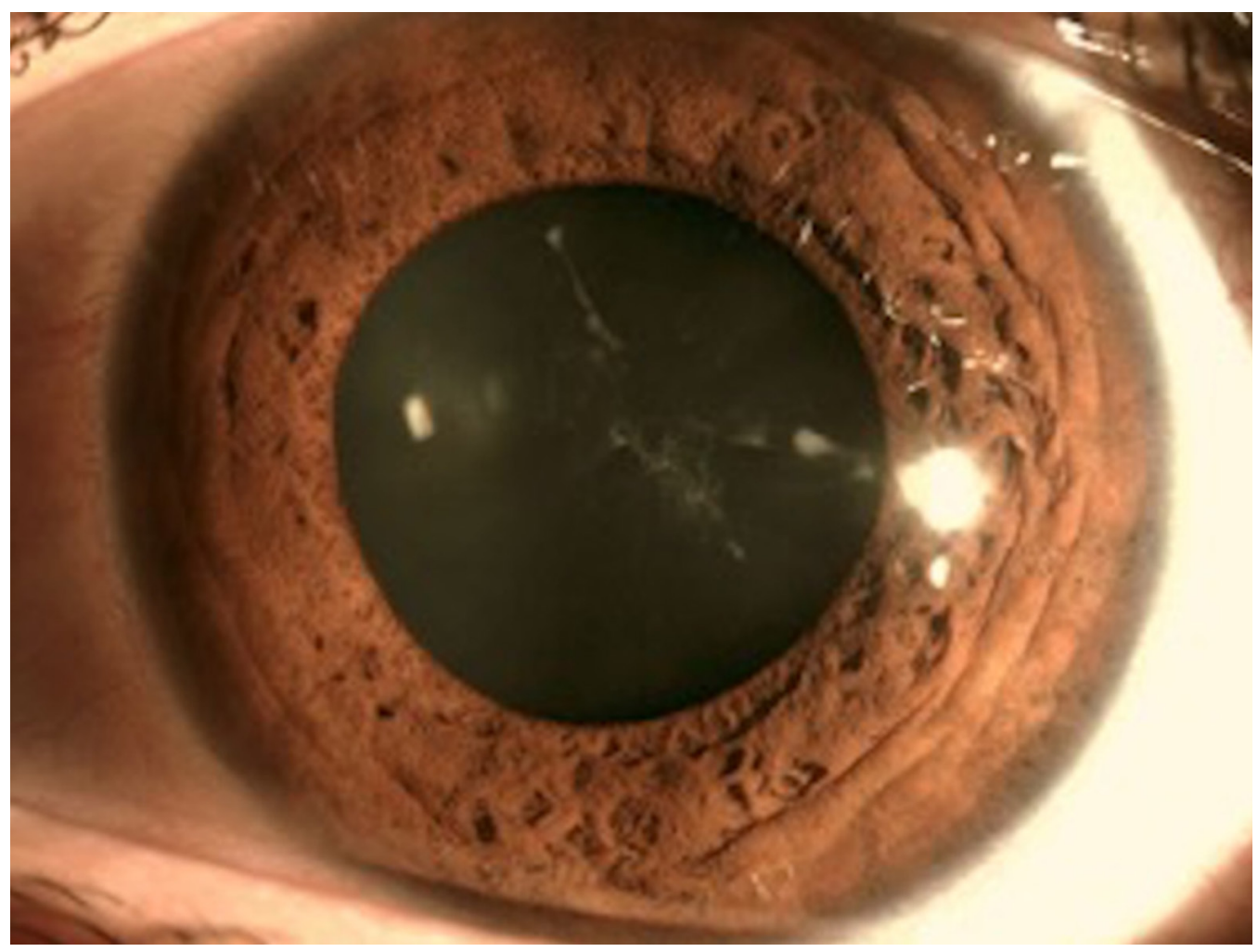

Figure 5. Development of opacity in the lens of the right eye in the 5th month.

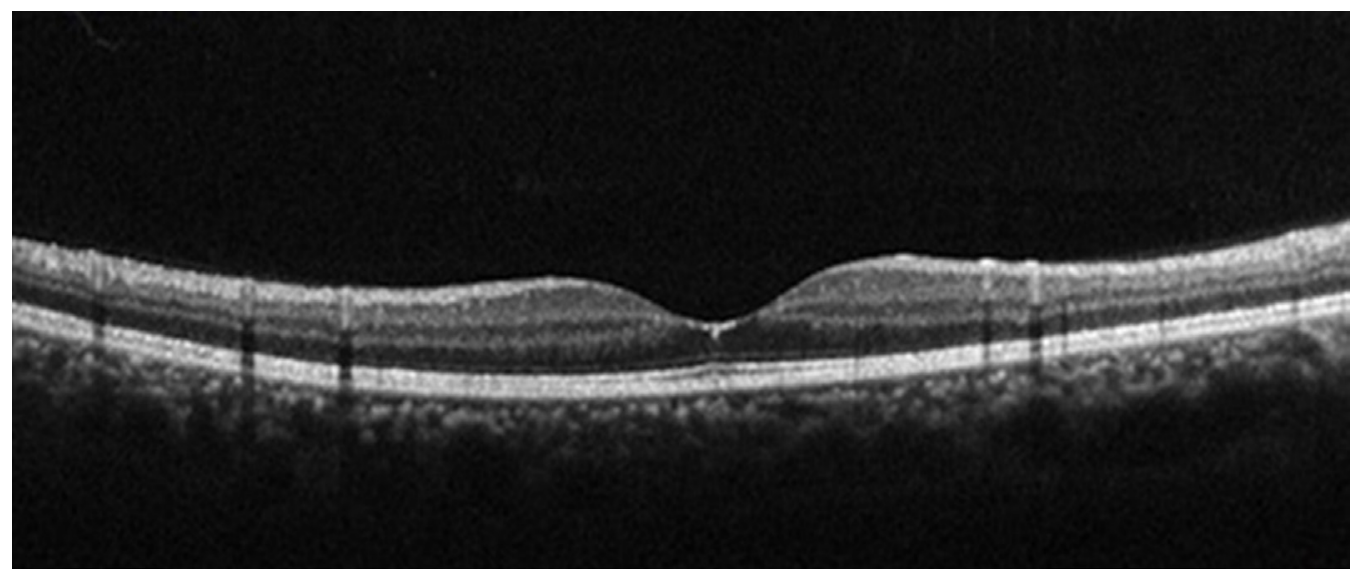

Figure 6. The subfoveal pseudocyst in the macula of the left eye disappeared by the 5th month. 


\section{Discussion}

Electrical energy transmitted in the living body results in the emergence of a variety of pathological findings due to the resulting cell destruction and edema. These findings develop via a range of mechanisms insulting the cell membrane integrity and altering the membrane potentials, which is a process known as electroporation ${ }^{13}$. An electrical current causes severe injuries in the tissues and organs at various levels including anatomical, histological, and biochemical findings ${ }^{14}$.

Superficial corneal lesions are common after lightning strike injuries. They resolve with symptomatic treatment or sometimes without treatment at all'. A posttraumatic corneal punctate epitheliopathy was detected in our patient and improved subsequently.

A lightning strike injury may cause the development opacity in the lens. Various mechanisms have been suggested to explain this finding including a decreased lens capsule permeability, the protein coagulation effect of the electric current, iritis-related impairment of lens nourishment, and mechanical damage to the lens fibers. Cataract formation usually starts in the eye close to the injury site and a mean time interval of 1-10 months may elapse for the cataract to be detected in the other eye. Morphologically, lightning-induced cataract presents with characteristic findings, affecting both the anterior and posterior capsules. Some degree of regression in transparency may subsequently be observed $^{15,16}$. A dilated fundus examination is important not to overlook an existing opacity when the lens periphery is involved. In our patient, the opacity developed in the lens of the left eye close to the site of the injury and it occurred in the subsequent fifth month following the lightning strike.

Inflammatory changes are common in the iris and the ciliary body ${ }^{7}$. Patients may have iritis attacks after a lightning strike. The presence of uveitis is usually associated with the presence of cataracts as it is suggested that the insult to the lens capsule results in the release of angiogenic substances ${ }^{13}$. An iridocyclitis attack occurred in our patient's left eye in the third month after the injury, but cataract was not detected at the dilated biomicroscopic examination. Inflammation and trauma are well-recognized causes of transient or permanent low IOP when the ciliary body is affected ${ }^{17}$. Decreased aqueous humor production or increased uveoscleral outflow are the two mechanisms suggested explaining an inflammation-induced ocular hypotony. They also cause ocular ischemia and low $\mathrm{IOP}^{18}$. Although a value of less than $10 \mathrm{mmHg}$ is generally believed to be necessary to determine the hypotony, clinical observations have determined structural and functional changes in the eye at values of $5 \mathrm{mmHg}$ or lower in most cases. Many eyes become symptomatic at IOP values of 5 $\mathrm{mmHg}$ and lower. While the mechanism involved in post-traumatic low IOP is unclear, the following factors have been suggested including a decreased aqueous humor production or an increased aqueous humor leakage or an insufficient aqueous humor production rate falling behind the aqueous humor outflow ${ }^{19}$. After trauma, large damage of ciliary body or cyclodialysis may cause hypotonia ${ }^{20}$. Hypotonia can be classified as temporary, chronic and permanent ${ }^{21}$. The low IOP was transient in our patient, lasting only one day.

Macular region is highly sensitive to thermal injuries. The lesions in this area may include macular edema, cyst, macular hole, and solar maculopathy ${ }^{9,10}$. In our patient, bilateral maculopathy was determined at the fundus examination on day 5 following the lightning strike injury. The subfoveal pseudocyst observed in the left eye at the macular OCT imaging was no longer present at the subsequent follow-up OCT images. The bilateral vision was normal with correction in the fifth month.

Lightning strike is a serious trauma with various ocular complications in affected cases. Complications such as corneal epithelial defect, transient ocular hypotonia, uveitis, maculopathy and cataract have occurred in this case. Patients should be followed regularly in eye clinics in terms of early, mid and late pathologies that may develop in such cases.

\section{Acknowledgment}

This study was presented as a poster at the 51st National Ophthalmology Congress, held on October 24-29, 2017, in Antalya, Turkey.

\section{References}

1. Cooper MA. Lightning injuries: Prognostic signs for death. Ann Emerg Med 1980;9(3):134-8.

2. Alyan O, Ozdemir O, Tufekcioglu O, Geyik B, Aras D, Demirkan D. Myocardial injury due to lightning strike--a case report. Angiology 2006;57(2):219-23.

3. Craig SR. When lightning strikes. Pathophysiology and treatment of lightning injuries. Postgrad Med 1986;79(4):109$12,121-4$. 
4. McIntyre WF, Simpson CS, Redfearn DP, Abdollah H, Baranchuk A. The lightning heart: A case report and brief review of the cardiovascular complications of lightning injury. Indian Pacing Electrophysiol J 2010;10(9):429-34.

5. Krishna A Rao, Lavanya G Rao, Ajay N Kamath, Vikram Jain. Bilateral macular hole secondary to remote lightning strike. Indian J Ophthalmol:2009;57:470-472.

6. Noel LP, Clarke WN, Addison D. Ocular complications of lightning. J Pediatr Ophthalmol Strabismus 1980;17:245-6.

7. Norman ME, Albertson D, Younge BR. Ophthalmic manifestations of lightning strike. Surv Ophthalmol 2001;46:19-24.

8. Cazabon S, Dabbs TR. Lightning-induced cataract. Eye 2000;14:903.

9. Handa JT, Jaffe GJ. Lightning maculopathy. A case report. Retina 1994;14:169-72.

10. Lee MS, Gunton KB, Fischer DH, Brucker AJ. Ocular manifestations of remote lightning strike. Retina 2002;22:808-10.

11. Lakosha H T. High-voltage electrical trauma to the eye. Can J Ophthalmol 2009;44(5):605-6.

12. Dimick AR. In: Fauci AS, Braunwald E, Isselbacher KJ, Wilson JD, Martin JB, Kasper DL, et al, editors. Harrison. s Principles of Internal Medicine, . Health Professions Division, 14th ed New York: McGraw-Hill; 1998. p.2559.
13. Jeanneth Toquica Osorio, MD, Hector Fernando Gómez Goyeneche, MD. Ocular Injuries Caused by Lightning Strikes: Review of the Literature and Presentation of Two Clinical Cases. Vis. Pan-Am 2016;15(3):84-86.

14. Buja Z, Arifi H, Hoxha E. Electrical burn injuries. An eight-year review. Ann Burns Fire Disasters 2010;23(1):4-7.

15. Biro Z, Pamer Z. Electrical cataract and optic neuropathy. Int Ophthalmol 1994;18:43-7.

16. Hanna C., and Fraunfelder F. T. Electric cataracts I. Sequential changes, Unusual and Prognostic Findings. II. Ultrastructural lens changes. Arch. Ophthalmol 87:184, 1972.

17. Fine HF, Biscette O, Chang S, Schiff WM. Ocular hypotony: a review. Compr Ophthalmol Update 2007 Jan-Feb; 8(1):29-37.

18. Schubert HD. Postsurgical hypotony: relationship to fistulization, inflammation, chorioretinal lesions, and the vitreous. SurvOphthalmol 1996;41:97-125.

19. Chun Ding and Jun Zeng. Clinical study on Hypotony following blunt ocular trauma. Int J Ophthalmol 2012;5(6):771-773.

20. Coleman DJ. Evaluation of ciliary body detachment in hypotony. Retina 1995;15(4):312-8.

21. Nalcı H, Hoşal MB, Yalçındağ N. Use of Ultrasound Biomicroscopy in the Diagnosis and Treatment of Chronic Ocular Hypotony. Turkiye Klinikleri J Ophthalmol 2019;28(1):1-6. 